\title{
Pressure Transmission of Acrylic and Porcelain Artificial Teeth on Thermoplastic Nylon Denture Base
}

\author{
Hubban Nasution ${ }^{1}$, Ika Andryas ${ }^{2}$ \\ ${ }^{1}$ Lecturer, Department of Prosthodontics, Faculty of Dentistry, Universitas Sumatera Utara, Medan, Indonesia. \\ ${ }^{2}$ Lecturer, Department of Prosthodontics, Faculty of Dentistry, Universitas Sumatera Utara, Medan, Indonesia. \\ *Corresponding author email : hubban.nasution@gmail.com \\ Authorsemail : andryas_doc@yahoo.co.id
}

\begin{abstract}
The pressure transmission under denture base may be different based on different artificial teeth. The purpose of this study was to evaluate pressure transmission of acrylic and porcelain artificial teeth on thermoplastic nylon denture base. Mandibular first molar acrylic and porcelain artificial teeth embedded on $15 \times 15 \times 3 \mathrm{~mm}^{3}$ thermoplastic nylon denture base were evaluated $(\mathrm{n}=16)$. A $100 \mathrm{~N}$ force was applied on the specimen using universal testing machine and the pressure transmitted under the specimen was observed using pressure transducer. The data were statistically analyzed with Mann-Whitney test $(\alpha=.05)$. Porcelain artificial teeth showed significantly higher pressure transmission than acrylic artificial teeth $(P<.05)$. This study can help dentists to determine the design of dentures, especially in the selection of artificial teeth material.
\end{abstract}

Keywords: Acrylic artificial teeth; denture base; thermoplastic nylon; porcelain artificial teeth; pressure transmission 


\section{INTRODUCTION}

Denture fabrication requires expertise and appropriate methods in order to have a convenient denture and does not cause a pathological condition in the oral cavity. Dentures must be designed properly to maintain oral tissue structure [1]. Previous study showed that the periodontal ligament fibroblasts started to respond alveolar bond remodeling from 20 to $50 \mathrm{mmHg}$ [2]. To keep blood circulation normal, continuous mechanical pressure higher than $1.3 \mathrm{kPa}$ should not be transferred to the supporting tissue of the dentures [3]. If the pressure changes the blood supply to the alveolar ridge or causes inflammation of the mucoperiosteum, pathological bone resorption can occur [4].

Along with the development of dental materials, thermoplastic resins are increasingly popular as denture base materials [5]. Thermoplastic resins have advantages such as favorable aesthetic, flexible, biocompatible and hypoallergenic properties [6]. Thermoplastic resins are divided into acrylic thermoplastic, acetal, polycarbonate, and polyamide (nylon). Thermoplastic nylon is a monomer-free base material which is an alternative for patients who are allergy to polymethyl methacrylate (PMMA) [7]. Nasution et al. evaluated the corellation of modulus of elasticity and nanohardness to pressure transmission at the thermoplastic denture base and PMMA denture base. They reported that denture base with higher modulus of elasticity and nanohardness would transmit and distribute greater pressure [8].In addition to the denture base selection, artificial teeth selection needs to be considered. Acrylic resin and porcelain artificial teeth are materials that are quite popular for fabrication of dentures [9]. Generally, porcelain artificial teeth show high abrasion resistance, excellent aesthetics and color stability, but it creates a clicking sound when in contact with the procelain antagonist artificial teeth and more expensive [10]. Acrylic artificial teeth are more clinically used than porcelain artificial teeth [11]. Mosharraf et al. reported that there were significant differences in the value of pressure transmission under denture bases using artificial teeth of different materials in direct and indirect tooth contacts [12]. Phunthikaphadr et al. also reported that there were significant differences in the value of pressure transmission and distribution under impact load using artificial teeth made of different materials [13]. This means that a suitable artificial teeth material should be selected for denture fabrication, especially when the pressure transmitted to the alveolar ridge is a concern.

The purpose of the present study was to evaluate the pressure transmission of acrylic and porcelain artificial teeth on thermoplastic nylon denture base. The null hypothesis was that there would be no difference in pressure transmission value of acrylic and porcelain artificial teeth on thermoplastic nylon denture base.

\section{MATERIAL AND METHODS}

Two different mandibular first molar artificial teeth; acrylic resin (BioEco, New Stetic, Bogota, Columbia) and porcelain (SMIC, Senju Metal Industry Co., Ltd, Tokyo, Japan) embedded on $15 \times 15 \times 3 \mathrm{~mm}^{3}$ thermoplastic nylon denture base (TCS, TCS Inc., California, USA) $(n=16)$. The specimens were prepared by using putty-type silicone impression material (Flexceed, GC India Dental Pvt Ltd., India) as a mold. Melted wax was poured into the mold; the artificial tooth was attached to the wax by using a surveyor to ensure that the occlusal surface of the artificial tooth was parallel to the base of the specimen.

Injection molding flasks were used to fabricate thermoplastic nylon denture base specimens. Wax replica of specimen with attached artificial tooth were invested into the flasks, boiled out, and placed into the injection molding machine. The cartridge containing thermoplastic nylon material was heated up according to the instructed temperature $\left(288^{\circ} \mathrm{C}\right.$ for 11 minutes $)$. Then the material within the cartridge was injected into the flask and allowed to being cool. The same method was used for maxillary artificial tooth as the antagonist specimen. All specimens were then removed from the denture flasks and the specimen surfaces were polished by using a rotary grinder with rotary speed $420 \mathrm{rpm}$ (Metaserv 250, Buehler, Illinois, USA). Abrasive paper grit number 500, 800, 1000, 1200 were used to polish the specimens. The specimens were immersed for 24 hours in deionized water at $37^{\circ} \mathrm{C}$ before testing. The schematic drawing of the specimen is shown in Fig. 1.

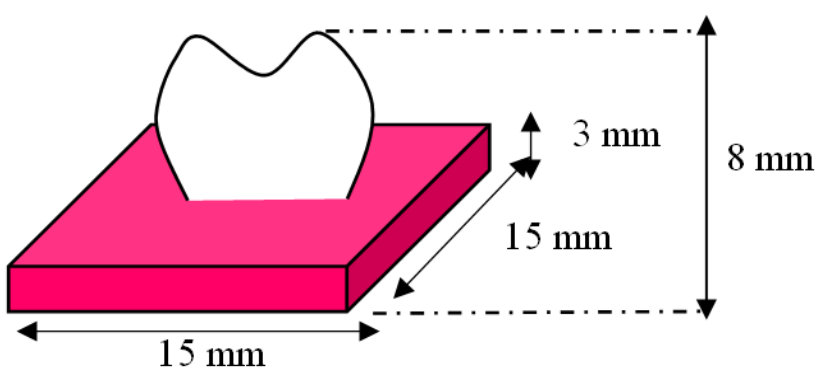

Figure 1. Schematic drawing of the specimen. 
The universal testing machine (EHF-EB100KN20L, Shimadzu Co., Kyoto, Japan) and pressure transducer was used to measure the pressure transmission under the specimen. After preparing all specimens, each pair of maxillary and mandibular denture teeth was arranged in a Class I Angle occlusal relationship. The pressure transducer was connected to universal testing machine. The maxillary artificial tooth specimen was placed at the indenter of the universal testing machine and the mandibular artificial tooth specimen was placed at the pressure transducer. A $100 \mathrm{~N}$ vertical force with cross-head speed 0.5 $\mathrm{mm} / \mathrm{min}$ was applied at the specimen and the pressure detected under the denture base was recorded. The testing apparatus is shown in Fig. 2.

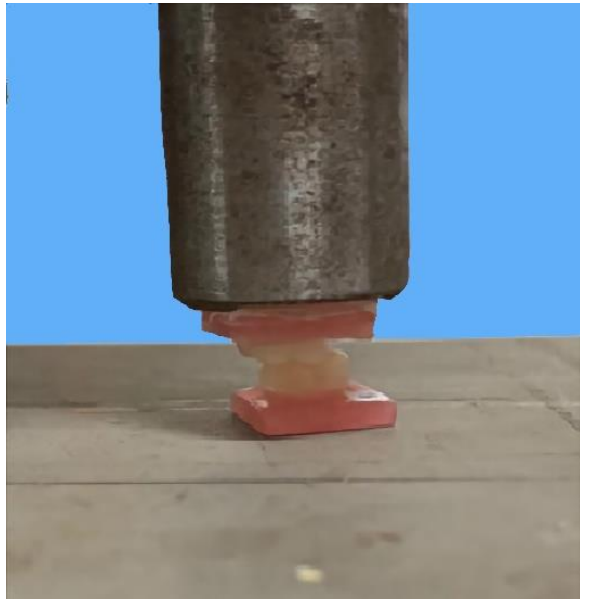

Figure 2. The testing apparatus.

Statistical software (SPSS Statistics V20; IBM Corp., NY, USA) was used for statistical analysis. Data were analyzed by using the Mann-Whitney test $(\alpha=0.05)$ since the data were not normally distributed.

\section{RESULTS}

The result of the statistical analysis of pressure transmission under thermoplastic nylon denture base using acrylic and porcelain artificial teeth is shown in Table 2.

Table 1. Mann-Whitney test for pressure transmission

\begin{tabular}{llccc}
\hline $\begin{array}{c}\text { Grou } \\
\text { ps }\end{array}$ & N & Mean & $\begin{array}{c}\text { S } \\
\text { D }\end{array}$ & $\begin{array}{c}\text { Mann- } \\
\text { Whitney } \\
\text { Test }\end{array}$ \\
\hline Acryl & 1 & 77.30 & 2. & 0.000 \\
ic & 6 & 4 & 38 & $P<.05$ \\
& & & 1 & \\
Porc & 1 & 90.21 & 3. & \\
\hline
\end{tabular}

\begin{tabular}{llll}
\hline elain & 6 & 3 & 13 \\
& & & 1 \\
\hline
\end{tabular}

Porcelain artificial teeth showed higher pressure transmission than acrylic artificial teeth $(P<.05)$. The mean of pressure transmission on the porcelain artificial teeth was $90.21 \pm 3.13 \mathrm{~N}$, while the pressure transmission on the acrylic artificial teeth was $77.30 \pm$ $2.38 \mathrm{~N}$.

\section{DISCUSSION}

The present study evaluated pressure transmission under thermoplastic nylon denture base with acrylic and porcelain artificial teeth. Statistical analysis showed the significant differences in pressure transmission under denture base using different artificial teeth; therefore, the null hypotheses was rejected.

Mastication force on the use of dentures would affect the shape of the alveolar bone. The pressure would be transmitted through the artificial teeth and denture base before being transferred to the alveolar ridge $[10,11]$. Denture base fabrication in the present study was controlled to be the same in each specimen and the size and shape of the artificial teeth used were equalized. Therefore, the results compared only the different artificial teeth materials.

The result showed that the porcelain artificial teeth have significantly higher pressure transmission than acrylic artificial teeth. The results of the present study corresponded to the previous studies [12,13]. Mosharraf et al. evaluated effect of artificial tooth material on load transmission under denture bases. They reported that the porcelain artificial teeth showed the highest pressure transmission among the others [12]. Phunthikaphadr et al. analyzed the role of modulus of elasticity of artificial teeth materials on the pressure transmission under denture base. The results obtained that porcelain artificial teeth which have a higher modulus of elasticity, transmitted greater pressure compared to acrylic artificial teeth. Artificial teeth with a lower modulus of elasticity can flex and absorb impact force and reduce pressure on the underlying structures [13].

Matsou et al. suggested that a pressure of 27 to 68 $\mathrm{g} / \mathrm{cm}^{2}$ would cause fibroblasts to increase intercellular calcium resulting in the alveolar bone remodeling [2]. Berg et al. reported that to keep blood circulation normal, continuous mechanical pressure higher than $1.3 \mathrm{kPa}$ should not be transferred to the supporting tissue of the dentures [3]. The pressure transmission values in present study were higher than those pressures because the size of the denture base 
specimen was only $225 \mathrm{~mm}^{2}$, thus the area to absorb pressure was limited. Therefore, maximum extension of denture base within anatomical and physiological limits is very recommended to increase the supporting area and minimize the pressure to alveolar ridge $[4,13]$.

The limitation of the present study were that pressure transmission were evaluated in vitro and the test equipment used could only measure the pressures without seeing its distribution pattern. Therefore, in vivo study is recommended.

\section{CONCLUSION}

Pressure transmission with porcelain artificial teeth was significantly higher than acrylic artificial teeth $(P<.05)$. Therefore, acrylic artificial teeth could be the choice of artificial teeth especially to reduce the pressure under thermoplastic nylon denture base.

\section{REFERENCES}

[1] Pradana FW, Dipoyono HM, Ismiyati T. Pembuatan gigi tiruan lengkap obturator rahang atas pada kasus Kelas III Arammany dengan penguat mini dental implant untuk protesa rahang bawah. Maj Ked Gi. 18 (2000) 68-72.

[2] Nakago-Matsou C, Matsou T, Nakago T. Intracellular calcium response to hydraulic pressure in human periodontal ligament fibroblasts. Am J Orthod Dentofac Orthop. 109 (1996) 244-8.

[3] Berg T Jr, Chase WW, Ray K. Denture base pressure tests. J Prosthet Dent. 17 (1967) 540-8.

[4] Arksornnukit M, Phunthikaphadr T, Takahashi H. Pressure transmission and distribution under denture bases using denture teeth with different materials and cuspal angulations. J Prosthet Dent. 105 (2011) 127-36.

[5] Perdana W, Diansari V, Rahmayani L. Distribusi frekuensi pemakaian gigi tiruan lepasan resin akrilik dan nilon termoplastik dibeberapa praktek dokter gigi di Banda Aceh. J Caninus Dent. 1 (2016) 1-5.

[6] Vojdani M, Giti R. Polyamide as a denture base material: a literature review. J Dent Shiraz Univ Med Sci. 16 (2015) 1-9.

[7] Kohli S, Bahtia, S. Polyamides in dentistry. IJSS. 1 (2013) 20-5.

[8] Nasution H, Kamonkhantikul K, Arksornnukit M, Takahashi H. Pressure transmission area and maximum pressure transmission of different thermoplastic resin denture base materials under impact load. J Prosthodont Res. 62 (2018) 44-9.

[9] Zarb GA, Bolender CL. Prosthodontic treatment for edentulous patients; complete dentures and implant-supported prostheses, twelve ed., Mosby, Philadelphia, 2000.

[10] Rangarajan V, Padmanabhan TV. Textbook of prosthodontics, second ed., Elsevier, India, 2017.

[11] Winkler S. Essentials of complete denture prosthodontics, second ed., Ishiyaku Euro America Inc, USA, 2000.

[12] Mosharraf R, Zisei F, Ahhasi M. Effect of denture tooth material on load transmission under denture bases. J Dent. 5 (2018) 325-31.

[13] Phunthikaphadr T, Takahashi H, Arksornnukit M. Pressure transmission and distribution under impact load using artificial denture teeth made of different materials. J Prosthet Dent. 102 (2009) 319-27 